\title{
PENGARUH PEMBERIAN TEPUNG KEONG SAWAH (Pila ampulacea) SEBAGAI PENGANTI TEPUNG IKAN DALAM PAKAN TERHADAP KUALITAS TELUR BURUNG PUYUH (Coturnix coturnix Japonica)
}

\author{
Crisye R. Rondonuwu, J. L. P. Saerang*, W. Utiah, M. N. Regar \\ Fakultas Peternakan Universitas Sam Ratulangi Manado, 95115
}

\begin{abstract}
ABSTRAK
Tujuan penelitian ini untuk mengetahui sejauh mana pengaruh pemberian tepung keong sawah (Pila ampulacea) sebagai pengganti tepung ikan dalam ransum burung puyuh (Coturnix coturnix japonica) terhadap kualitas fisik burung puyuh. Penelitian ini menggunakan 60 ekor burung puyuh betina berumur 5 minggu dan pengumpulan data dilakukan selama 8 minggu. Rancangan yang digunakan adalah rancangan rancangan acak lengkap (RAL) yang terdiri dari 4 perlakuan dan 5 ulangan. Perlakuan tersebut adalah tepung keong sawah dengan beberapa tingkat pemberian dalam ransum, yaitu; $\mathrm{R} 0=0 \%$ tepung keong sawah $+15 \%$ tepung ikan, $\mathrm{R} 1=5 \%$ tepung keong sawah $+10 \%$ tepung ikan, $\mathrm{R} 2=10 \%$ tepung keong sawah $+5 \%$ tepung ikan, $\mathrm{R} 3=15 \%$ tepung keong sawah $+0 \%$ tepung ikan. Variabel yang diukur dalam penelitian ini adalah berat telur, indeks kuning telur, indeks putih telur, warna kuning telur, dan tebal kerabang. Hasil analisis sidik ragam menunjukan bahwa tepung keong sawah memberikan pengaruh yang berbeda nyata $(\mathrm{P}<0,05)$ terhadap berat telur dan indeks putih telur dan tidak berbeda nyata terhadap perlakuan indeks kuning telur, warna telur, dan tebal kerabang telur burung puyuh. Berdasarkan hasil peneltian ini dapat disimpulkan bahwa pemberian tepung keong sawah sebanyak $15 \%$ sebagai pengganti tepung ikan dalam ransum burung puyuh petelur menghasilkan berat
\end{abstract}

*Korespondensi (corresponding author): Email: pinky_saerang@yahoo.com telur, indeks kuning telur, indeks putih telur, kerabang telur, dan warna kuning telur yang baik.

Kata kunci: tepung keong, tepung ikan, kualitas telur puyuh

\section{ABSTRACT}

SUBSTITUTION EFFECT OF FISH MEAL WITH SNAIL MEAL (Pila ampulacea) IN RATION ON QUILL EGG QUALITY (Coturnix coturnix Japonica). The objective of this study was to evaluate the substitution effect of fish meal with snail meal in ration on quill egg quality. Total of 60 quills at age of 5 weeks old were used on the period study of 8 weeks. The completely randomized design was applied in this study consisted of 4 treatments with 5 replications at each treatment. The treatments were levels of snail meal substituting fish meal in ration as follows: $\mathrm{R} 0=0 \%$ snail meal $+15 \%$ fish meal, $\mathrm{R} 1=5 \%$ snail meal $+10 \%$ fish meal, $\mathrm{R} 2=10 \%$ snail meal $+5 \%$ fish meal, $\mathrm{R} 3=$ $15 \%$ snail meal $+0 \%$ fish meal. Variables measured in this study were including egg weight, yolk index, albumin index, yolk color and shell thickness. Results showed that snail meal affected significantly $(\mathrm{P}<0.05)$ the egg weight and albumin index, did not affect yolk index, yolk color and shell thickness. Therefore, it can be concluded that substitution of fish meal with snail meal up to $15 \%$ in ration of quill produced good products of egg weight, 
yolk index, albumin index, yolk color and shell thickness.

Key words: Snail meal, fish meal, quill egg quality.

\section{PENDAHULUAN}

Burung puyuh sampai saat ini masih dipandang sebagai unggas penghasil telur. Berbagai upaya telah dilakukan untuk meningkatkan performans puyuh petelur diantaranya dengan perbaikan ransum yang diberikan, namun perbaikan ransum sering menjadi dilematis terkait dengan biaya produksi ransum yang mencapai sekitar $70 \%$ dari biaya produksi. Pada setiap tahap perkembangannya, puyuh membutuhkan ransum dengan kualitas yang berbeda. Umumnya perbedaan kualitas ransum ditandai dengan kadar protein kasar yang terkandung di dalam ransum tersebut. Ransum yang diberikan harus mengandung nutrient yang sesuai kebutuhannya yaitu dengan protein $20 \%$ untuk layer dengan EM (Energi Metabolisme) sebesar 2900 $\mathrm{kkal} / \mathrm{kg}$ (NRC, 1994).

Keong sawah (Pila ampullacea) adalah sejenis siput air tawar dan mudah dijumpai di sawah. Bentuknya menyerupai siput keong mas (murbai), tetapi keong sawah memiliki warna cangkang hijau pekat sampai hitam. Jumlah keong sawah paling banyak berada di sekitar parit sawah karena dianggap menjadi hama bagi tanaman, banyak petani mengambil dan membasmi keong sawah. Keong sawah dapat dimanfaatkan sebagai bahan pakan sumber protein karena mengandung protein $51,08 \%$. Namun pemanfaatan keong sawah sebagai bahan pakan belum dilakukan secara optimal. Selain kandungan proteinnya yang tinggi harga keong sawah juga relatif murah jika dibandingkan dengan bahan ransum lain. Disamping lebih murah, ketersediaannya berlimpah sehingga dapat dihasilkan sebagai bahan ransum alternatif sumber protein hewani.

Dari uraian pembahasan di atas maka telah dilakukan penelitian yang bertujuan untuk melihat pengaruh pemberian tepung keong sawah (pila ampulace) sebagai pengganti tepung ikan dalam pakan terhadap kualitas telur burung puyuh.

\section{MATERI DAN METODE PENELITIAN}

Penelitian ini dilaksanakan di Laboratorium Produksi dan Laboratorium Teknologi Hasil Ternak Fakultas Peternakan Universitas Sam Ratulangi dengan menggunakan 60 ekor burung puyuh betina yang berumur 5 minggu. Kandang yang digunakan adalah kandang batere dengan ukuran 40 x 30 × $30 \mathrm{~cm}$ sebanyak 2 unit. Ransum yang digunakan 
Tabel 1. Komposisi zat - zat makanan bahan pakan dan penyusun ransum

\begin{tabular}{|c|c|c|c|c|c|c|}
\hline Bahan Makanan & Protein & SK & Lemak & $\mathrm{Ca}$ & $\mathrm{P}$ & EM \\
\hline Jagung $^{1)}$ & 9,42 & 2,15 & 3,90 & 0,22 & 0,60 & 2982,00 \\
\hline Dedak halus ${ }^{1)}$ & 9,90 & 6,35 & 6,07 & 0,19 & 0,73 & 2696,00 \\
\hline Tepung kedele ${ }^{4)}$ & 37,50 & 2,00 & 12,52 & 0,24 & 0,208 & 2540,00 \\
\hline Tepung Ikan ${ }^{1)}$ & 55,59 & 0,02 & 9,00 & 5,10 & 2,08 & 3880,00 \\
\hline Keong sawah ${ }^{3)}$ & 15.00 & 6,09 & 2.40 & 5.87 & 0.98 & 900,67 \\
\hline Bungkil kelapa $^{1)}$ & 21,00 & 15,02 & 9,36 & 0,87 & 0,47 & 3200,00 \\
\hline $\mathrm{CaCO}^{2)}$ & & & & 40,00 & & \\
\hline
\end{tabular}

1). Menurut Dengah et al. (2016)

2). Menurut Scott et al. (1982)

3). Hasil analisis Laboratorium Ilmu dan Teknologi Pakan Fakultas Peternakan IPB

4). Hasil perhitungan Tabel komposisi nutrisi bahan ransum NRC (1994)

Tabel 2. Ransum Penelitian

\begin{tabular}{|c|c|c|c|c|}
\hline \multirow[t]{2}{*}{ Bahan Makanan } & \multicolumn{4}{|c|}{ Jumlah (\%) } \\
\hline & R0 & R1 & R2 & R3 \\
\hline Jagung & 52,00 & 52,00 & 52,00 & 52,00 \\
\hline Dedak halus & 10,00 & 10,00 & 10,00 & 10,00 \\
\hline Tepung kedele & 13,00 & 13,00 & 13,00 & 13,00 \\
\hline Tepung ikan & 15,00 & 10,00 & 5,00 & 0,00 \\
\hline Keong sawah & 0,00 & 5,00 & 10,00 & 15,00 \\
\hline Bungkil kelapa & 8,00 & 8,00 & 8,00 & 8,00 \\
\hline $\mathrm{CaCO}_{3}$ & 2,00 & 2,00 & 2,00 & 2,00 \\
\hline Total & 100 & 100 & 100 & 100 \\
\hline \multirow{2}{*}{ Kandungan Zat-zat Makanan } & \multicolumn{4}{|c|}{ Persentase (\%) } \\
\hline & R0 & R1 & R2 & R3 \\
\hline Protein $(\%)$ & 20,78 & 19,41 & 17,38 & 15,35 \\
\hline SK (Serat Kasar) (\%) & 3,22 & 3,52 & 3,82 & 4,13 \\
\hline Lemak $(\%)$ & 6,83 & 6,34 & 6,86 & 5.37 \\
\hline $\mathrm{Ca}($ Kalsium $)(\%)$ & 1,74 & 1,78 & 1,82 & 1,85 \\
\hline $\mathrm{P}$ (Fosfor) (\%) & 0,77 & 0,72 & 0,66 & 0,60 \\
\hline ME (kkal) (\%) & 2986,64 & 2898,44 & 2810,24 & 2722,04 \\
\hline
\end{tabular}


adalah ransum halus yang terdiri atas jagung kuning, dedak halus, bungkil kelapa, tepung kedele, tepung ikan, $\mathrm{CaCO}_{3}$, dan tepung keong sawah (Pila ampulacea). Komposisi zat - zat makanan dan ransum penelitian dapat dilihat pada Tabel 1 dan Tabel 2.

\section{Metode Peneltian}

Penelitian ini menggunakan Rancangan Acak Lengkap (RAL) menurut Steel \& Torrie (1994) yang terdiri dari 4 perlakuan dan 5 ulangan dengan model matematis sebagai berikut.

$\mathrm{Yij}=\pi+\tau i+\sum i j$

Ket :

$$
\begin{aligned}
\mathrm{i}= & 1,2,3,4 \text { (perlakuan) } \\
\mathrm{j}= & 1,2,3,4,5 \text { (ulangan) } \\
\mathrm{Yij}= & \text { Respon pengamatan satuan } \\
& \text { percobaan yang memperoleh } \\
& \text { perlakuan ke } \mathrm{j} . \\
\pi \quad= & \text { rataan umum } \\
\tau \mathrm{i}= & \text { pengaruh perlakuan ke- } \mathrm{i} \\
\Sigma \mathrm{ij}= & \text { pengaruh galat }
\end{aligned}
$$

Data yang diperoleh di analisis ragam dan apabila terdapat perbedaan dilanjutkan dari uji beda nyata jujur (BNJ).

\section{Variabel yang diamati}

a. Berat telur

Telur yang sudah disimpan di tray dikelompokkan berdasarkan perlakuan dan ulangan. Kemudian telur ditimbang untuk memperoleh berat telur/butir dengan menggunakan timbangan O-Hause. b. Indeks kuning telur

Nilai indeks kuning telur digunakan untuk mengetahui kekentalan kuning telur (Suprijatna et al., 2008). Komponen yang digunakan untuk mengukur indeks kuning telur adalah tinggi kuning telur dan diameter kuning telur (Sirait, 1986). Nilai yang diperoleh dimasukkan dalam formulasi sebagai berikut.

Indeks Kuning Telur $=\frac{\text { Tinggi kuning telur }}{\text { Diameter kuning telur }}$

c. Indeks Putih telur Indeks albumen adalah rasio tinggi albumen kental terhadap rata rata diameter terpanjang dan terpendek dari albumen. Telur dipecahkan dan diletakan di atas kaca, kemudian tingi dan diameter putih telur dukur. Indeks putih telur dihitung menggunakan rumus (Muchtadi dan Sugiyono 1992). Indeks putih telur= $\frac{\text { Tinggi putih telur }}{\text { Diameter putih telur }}$

d. Ketebalan kerabang telur

Telur dipecahkan dengan hati-hati kemudian bagian kerabang telur di ujung tumpul, tengah, dan ujung runcing diambil dan diukur dengan menggunakan mikrometer scrub. Tebal kerabang telur diukur dengan 
menggunakan rumus sebagai berikut (Ramanoff dan Ramanoff, 1963)

Tebal kerabang $=\frac{\mathrm{t} 1+\mathrm{t} 2+\mathrm{t} 3}{3}$

Ket: $\mathrm{t} 1, \mathrm{t} 2, \mathrm{t} 3=$ tebal kerabang pada ujung tumpul, tengah dan runcing.

e. Warna kuning telur

Pengukuran skor warna kuning telur dilakukan dengan cara mencocokkan warna kuning telur dengan warna standar yang terdapat pada kipas kuning telur atau egg yolk colour fan (Bovšková et at. 2014).

\section{HASIL DAN PEMBAHASAN}

\section{Pengaruh Perlakuan Terhadap Berat Telur}

Rataan pengaruh perlakuan terhadap berat telur burung puyuh dapat dilihat pada Tabel 3. Rataan berat terlur berkisar antara 7,98 - 8,96 gram per butir.
Hasil analisis sidik ragam menunjukan perlakuan memberikan pengaruh berbeda nyata terhadap berat telur. Hasil uji lanjut BNJ menunjukan perlakuan R2 nyata lebih tinggi dari perlakuan R0, R1 dan R3. Sementara diantara R0, R1, dan R3 tidak terdapat perbedaan. Berat telur merupakan sifat kuantitatif yang dapat diturunkan yang dipengaruhi oleh jenis pakan, jumlah pakan, lingkungan kandang serta besar tubuh induk sangat mempengaruhi berat telur (Listiyowati dan Roospitasari, 2009). Anggorodi (1995) juga menyatakan bahwa telur puyuh mempunyai berat $7 \%-8 \%$ dari berat induk yaitu berkisar $7-11$ gram per butir. Setilawarti et al. (2013) juga menambahkan bahwa berat telur puyuh berkisar antara 8,26 - 8,47 gram. Hasil penelitian ini masih berada pada kisaran berat telur dalam hasil penelitian yang telah dilakukan oleh peneliti-peneliti sebelumnya.

Tabel 3. Rataan Pengaruh perlakuan terhadap Kualitas Terlur Burung Puyuh

\begin{tabular}{lcccc}
\hline \multirow{2}{*}{ Variabel } & \multicolumn{4}{c}{ Perlakuan } \\
\cline { 2 - 5 } & $\mathrm{R} 0$ & $\mathrm{R} 1$ & $\mathrm{R} 2$ & $\mathrm{R} 3$ \\
\hline Berat Telur (gram) & $8,34^{\mathrm{a}}$ & $8,17^{\mathrm{a}}$ & $8,96^{\mathrm{b}}$ & $798^{\mathrm{a}}$ \\
Indeks Kuning Telur & 0,35 & 0,36 & 0,33 & 0.36 \\
Indeks Putih Telur & $0,69^{\mathrm{ab}}$ & $0,58^{\mathrm{ab}}$ & $0,54^{\mathrm{a}}$ & $0.74^{\mathrm{b}}$ \\
Tebal Kerabang (mm) & 0,194 & 0,190 & 0,188 & 0.180 \\
Warna Kuning Telur & 5,43 & 5,94 & 6,09 & 5,77 \\
\hline
\end{tabular}

Keterangan: Superskrip pada baris yang sama menunjukkan perbedaan nyata $(\mathrm{P}<0,05)$ 


\section{Pengaruh Perlakuan Terhadap Indeks Kuning Telur}

Rataan pengaruh perlakuan terhadap indeks kuning telur burung puyuh dapat dilihat pada Tabel 3. Rasio indeks kuning telur pada penelitian ini adalah 0,33 $-0,36$. Indeks putih telur dan indeks kuning telur menunjukan mutu kesegaran dari telur. Hasil analisis ragam pengaruh perlakuan terhadap indeks kuning telur tidak menunjukan perbedaan $(\mathrm{P}>0.05)$. Ganchev (2012) dalam penelitiannya menyatakan bahwa indeks kuning telur bervariasi antara 0,234 dan 0,577 dengan kualitas yang paling stabil antara produksi bulan ke 3 dan 5. Sesuai dengan hasil penelitian Imai et al. (1984) dalam Shinta et al. (2012) bahwa indeks kuning telur puyuh umur satu hari adalah 0,52.

\section{Pengaruh Perlakuan Terhadap Indeks Putih Telur}

Rataan pengaruh perlakuan terhadap indeks putih telur burung puyuh dapat dilihat pada Tabel 3. Rasio indeks putih telur pada penelitian ini adalah $0,54-$ 0,74. Romanof dan Romanoff dalam Elvira (1994) menyatakan bahwa indeks putih telur yang baru di peroleh bervariasi antara 0,050 - 0,174. Hasil analisis sidik ragam pengaruh perlakuan terhadap indeks putih telur menunjukan perbedan yang nyata $(\mathrm{P}<0.05)$. Berdasarkan uji BNJ Perlakuan
R2 dam R3 menunjukan perbedaan yang nyata. Sementara perlakuan R0, R1 dan R2 tidak menunjukan adanya perbedaan. Protein pakan akan memberi pengaruh pada viskositas telur yang kemudian mempengaruhi indeks albumen, dimana indeks albumen itu sendiri ditentukan oleh tinggi putih telur kental dan diameternya, sehingga indeks albumen telur sangat dipengaruhi oleh protein pakan (Argo et al. 2013)

\section{Pengaruh Perlakuan Terhadap Tebal Kerabang Telur}

Tebal kerabang telur puyuh menunjukan kualitas ketahanan telur paling luar. Rataan tebal kerabang telur puyuh dapat dilihat pada Tabel 3. Berdasarkan hasil analisis sidik ragam pengaruh perlakuan terhadap tebal kerabang telur tidak memberikan perbedaan nyata (P>0.05). Wahyu (1985) menyatakan bahwa kulit telur itu sebagian terdiri dari kalsium karbonat, maka faktor yang menentukan untuk pembentukan kerabang (kulit telur) adalah kalsium (Ca) dan phospor, walaupun dalam jumlah kecil, phospor berperan penting dalam transportasi kalsium ketika kerabang telur dibentuk (Amrullah, 2004). Menurut Vilchez et al. (1992), tebal kerabang ditambah selaput telur berkisar antara 0,176-0,184 mm. Tebal kerabang dalam 
penelitian ini masih lebih tinggi dibandingkan dengan penelitian dari Amin

\section{KESIMPULAN}

et al. (2015), yaitu tebal kerabang berkisar antara $0.17 \mathrm{~mm}-0.18 \mathrm{~mm}$. Hal ini disebabkan karena kandungan $\mathrm{Ca}$ dalam tepung keong sawah lebih tinggi dengan kandungan Ca pada tepung keong ikan.

\section{Pengaruh Perlakuan Terhadap Warna Kuning Telur}

Rataan pengaruh perlakuan terhadap warna kuning telur burung puyuh dapat dilihat pada Tabel 3. Rasio warna kuning telur puyuh berkisar antara 5,43 6,09. Hasil analisis sidik ragam menunjukan bahwa pengaruh perlakuan terhadap warna kuning telur tidak memberikan perbedaan yang nyata (P>0.05). Menurut Tuti (2009) kualitas indeks kuning telur bergantung pada besar kuning telur. Kang et al. (2003) menambahkan warna kuning telur dipengaruhi oleh pigmen karoten. Skor warna kuning telur penelitian ini sangat rendah dibandingkan dengan penelitian yang dilakukan oleh Claudia (2014) dengan rataan skor warna kuning telur $6.60-7,80$. Amrullah (2004) menyatakan bahwa laju produksi telur menyebabkan keragaman warna kuning telur ketika produksi telur meningkat, xantofil dalam ransum menyebar ke banyak kuning telur sehingga warna kuning telur menurun dan sebaliknya.

1. Pemberian tepung keong sawah $10 \%$ sebagai pengganti tepung ikan dalam ransum burung puyuh petelur menghasilkan indeks kuning telur, kerabang telur dan warna kuning telur yang baik. Sedangkan indeks putih telur menunjukan perbedaan yang nyata pada R2 dan R3.

2. Pemberian tepung keong sawah $10 \%$ sebagai pengganti tepung ikan dalam ransum burung puyuh petelur menghasilkan berat telur yang baik (R2).

\section{DAFTAR PUSTAKA}

Anggorodi, H.R, 1995. Nutrisi Aneka Ternak Unggas. PT Gramedia Pustaka Utama, Jakarta.

Amrullah, I.K. 2004. Nutrisi Ayam Broiler. Cetakan III. Lembaga Satu Gunungbudi. Bogor.

Amin, N.S., E. Anggraeni, Dihansih. 2015. Pengaruh Penambahan Larutan Ekstrak Kunyit (Curcuma domesticca) Dalam Air Minum Terhadap Kualitas Telur Puyuh. Jurnal Peternakan Nusantara. Vol 1(2): 115.

Argo, L.B., I. Tristiarti, I. Mangisah. 2013. Kualitas telur ayam arab petelur fase I dengan berbagai level Azolla microphylla. Animal Agricultural Journal. 2(1): 445-447. 
Bovšková, H., K. Míková, Z. Panovská. 2014. Evaluation of egg yolk colour. Czech J. Food Sci. 32: 213-217.

Elvira, S., Soewarno, T. Soekarto, S.M. Supraptini. 1994. Studi komporatif sifat mutu dan fungsional telur puyuh dan telur ayam ras. Bul-Tek. Industri Pangan Vol V (3)

Kang, D. K., S. I. Kim, C. H. Cho, Y. H. Yim, dan H. S. Kim. 2003. Use of lycopine, an antioxidant carotenoid, in laying hens for egg yolk pigmentation. Asian-Aust. J. Anim. Sci. 16 (12): 1799-1803

Listiyowati, E. dan K. Roospitasari. 2000. Puyuh: Tata Laksana Budi Daya Secara Komersial. Penebar Swadaya, Jakarta.

Muchtadi, T.R., Sugiono. 1992. Ilmu Pengetahuan Bahan Pangan. Departemen Pendidikan dan Kebudayaan. Direktorat Jenderal Tinggi Pusat Antar Universitas Pangan dan Gizi. Bogor: Institut Pertanian Bogor.

NRC [National Research Council]. 1994. Nutrient Requirements of Poultry. Ed Rev ke-9. Washington DC. Academy Pr.

Rondonuwu, C., J.L.P. Saerang, F. Nangoy, S. Laatung. 2014. Penambahan rimpang kunyit (Curcma domestica Va), temulawak (Curcuma xanthorrhiza Roxb), dan temu putih Curcuma Zedoaria Rosc.) dalam ransum komersil terhadap kualitas telur burung puyuh (Coturnix coturnix Japonica). Jurnal Zootek 34(1):106-113

Shinta, D.K., K. Praseno, Kasiyati. 2012. Indeks kuning telur (IKT) dan haugh unit (HU) telur puyuh hasil pemeliharaan dengan pemberian larutan mikromineral ( $\mathrm{Fe}, \mathrm{Co}, \mathrm{Cu}, \mathrm{Za})$ dan vitamin (A, B, B12, C) Sebagai drinking water. Buletin Anatomi Dan Fisiologi Volume XX (2):

Sirait, C.H. 1986. Telur dan Pengolahannya. Pusat Penelitian Pengembangan Peternakan. Bogor.

Steel, R.G..D., J.H. Torrie, 1994. Prinsip dan Prosedur Statistika Suatu Pendidikan Giometrik, PT. Gramedia Pustaka Utama. Jakarta`.

Suprijatna, E.S., Kismiati, N.R. Furi. 2008. Penampilan produksi dan kualitas telur pada puyuh (Coturnix-coturnix japonica) yang memperoleh ransum protein rendah disuplementasi enzim komersial. J. Indonesia. Trop. Anim. Agric. 33 (1): 68.

The., C.L.K. Sarajar, M.E.R. Montong, M. Najoan. 2017. Performans burung puyuh (Coturnix - coturnix japonica) yang diberikan tepung keong sawah (pila ampulacea) sebagai pengganti tepung ikan dalam ransum. Jurnal Zootek 37(1): $62-69$.

Tuti, W. 2009. Pemanfaatan Tepung Daun Pepaya (Carica Papaya. L L ess) dalam upaya peningkatan produksi dan kualitas telur ayam sentul. J. Agroland. 16(3): 268-273.

Vilchez, CSP. Touchburn, ER. Chavez, Laque PC. 1992. Research Note: Eggshell quality in japanese quail feed different fatty acid. Poultry Sci. 71: 1568-1571.

Wahyu J. 1992. Ilmu Nutrisi Unggas. Yogyakarta: Gadjah Mada University Press. 